\title{
Decreased energy intake versus increased lipolysis in the prevention of type 2 diabetes
}

\author{
Katsunori Nonogaki* \\ Department of Diabetes Technology, Tohoku University Graduate School of Biomedical Engineering, Japan
}

A World Health Organization report says that taxing sugary drinks can lower consumption and reduce obesity and type 2 diabetes. Reduced consumption of sugary drinks means lower intake of calories overall and fewer people suffering from obesity and diabetes. It is well known that obesity results from increased energy intake and decreased energy expenditure. In the past decade, most of anti-obesity agents, however, have the inhibitory effect on energy intake rather than the stimulatory effect on energy expenditure. A high dose of liraglutide ( $3 \mathrm{mg}$ ), a human glucagon-like-peptide-1 (GLP-1) analog, which treats type 2 diabetes, was recently approved by the European Medicines Agency and United States Food and Drug Administration for weight reduction in human obesity [1]. The novel mechanisms by which liraglutide reduces obesity and hyperglycemia have been recently elucidated.

Systemic administration of liraglutide decreases food intake, body weight, and blood glucose levels independently of insulin and glucagon in obese and diabetic $\mathrm{KKA}^{\mathrm{y}}$ mice with ectopic overexpression of agouti peptide, an endogenous melanocortin-4 receptor antagonist [2]. On the other hand, despite remarkably increased plasma active GLP-1 levels, the ingestion of alogliptin, a selective dipeptidyl peptidase-4 (DPP-4) inhibitor, has no effects on food intake, body weight, and blood glucose levels in $\mathrm{KKA}^{\mathrm{y}}$ mice [2]. The anti-diabetic effect of liraglutide therefore results from the decreased energy intake rather than the insulinotropic action in $\mathrm{KKA}^{\mathrm{y}}$ mice. Recent report by Nagakubo et al. also supported this evidence and demonstrated that the anti-diabetic effect of liraglutide results from the inhibitory action of food intake in diabetic WBKDF rats with obesity and insulin deficiency [3]. Thus, liraglutide and the DPP-4 inhibitors can have different actions on diabetes and obesity.

Central GLP-1 receptors reportedly mediate body weight and anorectic effects of liraglutide [4] and central injection of liraglutide reduces body weight via decreased energy intake rather than increased energy expenditure in mice [5]. Although recent reports suggested that proopiomelanocortin (POMC) and cocaine and amphetamineregulated transcript (CART) in the arcuate nucleus of the hypothalamus largely mediate chronic administration of liraglutide-induced feeding suppression in rats or mice [6,7], the anorexic effect of liraglutide actually occurs within 1 hour after the administration in mice [8]. The acute anorexic effect of liraglutide does not require functional leptin receptor, serotonin, and hypothalamic POMC and CART activities in mice [8].

In the white adipose tissue of obese mice, expression of $\beta$-Kotho, fibroblast growth factor receptor (FGFR)-1c and 2c, which bind FGF21,

Copyright: (C2016 Nonogaki K. This is an open-access article distributed under the terms of the Creative Commons Attribution License, which permits unrestricted use, distribution, and reproduction in any medium, provided the original author and source are credited. is decreased. Treatment with mouse monoclonal FGFR2-IIIc antibody suppresses body weight gain and epididymal white adipose tissue weight by increased lipolysis in $\mathrm{KKA}^{\mathrm{y}}$ mice while having no effect on daily food intake, blood glucose levels, and the expression of uncoupling protein-1, uncoupling protein-2 or peroxisome proliferator-activated receptor- $\gamma$ coactivator $1 \alpha$ in the epididymal white adipose tissue [9]. These findings suggest that the reduction of weight gain and adiposity induced by increased lipolysis without decreased energy intake might not lead to the prevention of type 2 diabetes. Reduced consumption of calories overall including sugary drinks will be beneficial for the prevention of type 2 diabetes.

\section{References}

1. Bray GA (2015) Obesity: liraglutide-another weapon in the war against obesity? Nat Rev Endocrinol 11: 569-570.[crossref]

2. Nonogaki K, Hazama M, Satoh N (2014) Liraglutide suppresses obesity and hyperglycemia associated with increases in hepatic fibroblast growth factor 21 production in KKAy mice.Biomed Res Int 2014: 751930.[crossref]

3. Nagakubo D, Shirai M, Wakabayashi K, Nakamura Y, Kaji N, et al. (2016)Therapeutic effects of liraglutide, a glucagon-like peptide-1analog, in diabetic WBN/Kob-Leprfarats with obesity andchronic pancreatitis.Integr Obesity Diabetes 2: 265-270.[crossref]

4. Sisley S, Gutierrez-Aguilar R, Scott M, D’Alessio DA, Sandoval DA, Seeley RJ (2014) Neuronal GLP1R mediates liraglutide's anorectic but not glucose-lowering effect.J Clin Invest 124: 2456-2463. [crossref]

5. Nonogaki K, Kaji T, Yamazaki T, Murakami M (2016) Pharmacologic stimulation of central GLP-1 receptors has opposite effects on the alterations of plasma FGF21 levels induced by feeding and fasting.NeurosciLett 26: 612:614.[crossref]

6. Secher A, Jelsing J, Baquero AF, Hecksher-Sørensen J, Cowley MA, et al. (2014) The arcuate nucleus mediates GLP-1 receptor agonist liraglutide-dependent weight loss. $J$ Clin Invest 124: 4473-4488. [crossref]

7. Barreto-Vianna ARC, Aguila MB, Mandarim-de-Lacerda CA (2016) Effects of liraglutide in hypothalamic arcuate nucleus of obese mice.Obesity 24: 626-633. [crossref]

8. Nonogaki K, Kaji T (2016) The acute anorexic effect of liraglutide, a GLP-1 receptor agonist, does not require functional leptin receptor, serotonin, and hypothalamic POMC and CART activities in mice. Diabetes Res ClinPract 120: 186-189.[crossref]

9. Nonogaki K, Kaji T, Yamazaki T, Murakami M (2016) Treatment with FGFR2IIIc monoclonal antibody suppresses weight gain and adiposity in $\mathrm{KKA}^{\mathrm{y}}$ mice.Nutr Diabetes 6: e233.[crossref]

Correspondence to: Katsunori Nonogaki, Professor, Department of Diabetes Technology, Tohoku University Graduate School of Biomedical Engineering, 6-6-11 Aramakiaza-aoba, Aoba-ku, Sendai, Miyagi 980-8579, Japan, E-mail: katsu@trc.med.tohoku.ac.jp or knonogaki-tky@umin.ac.jp; Fax: +81-22-7953865, Phone: +81-22-795-3865

Received: December 04, 2016; Accepted: December 17, 2016; Published: December 20, 2016 